\title{
Effects of salinity on larval and early juvenile growth of an extremely euryhaline crab species, Armases miersii (Decapoda: Grapsidae)
}

\author{
Klaus Anger*, Kim Riesebeck \& Cornelia Püschel \\ Alfred-Wegener-Institut für Polar- und Meeresforschung; Biologische Anstalt Helgoland, Meeresstation, \\ D-27498 Helgoland, Germany (*author for corespondence)
}

Key words: decapod larvae, salinity tolerance, larval growth, carbon, osmoregulation

\begin{abstract}
The neotropical crab Armases miersii (Rathbun, 1897) breeds in supratidal rock pools, where great salinity variations occur. In laboratory experiments, all larval stages and the first juveniles were reared at six different salinities (5-55 PSU, intervals of 10 PSU). In five series of experiments, exposure to these conditions began either from hatching (Zoea I) or from the onset of successively later stages (Zoea II, III, Megalopa, Crab I). Growth was measured in terms of dry weight, carbon, nitrogen and hydrogen content. At osmotically extreme conditions (5 and 55 PSU, resp.), all stages showed minimum biomass accumulation; this was consistent with maximum mortality and longest duration of development (data presented in a separate paper). Successively later exposure to these salinities tended to reduce these effects. Lowest mortality and shortest time of development occurred generally at 15-25 PSU, indicating an optimum at moderately reduced salinities. This response pattern, however, was not congruent with that observed in growth. Biomass accumulation was initially maximum within a wide range of salinities (15-45 PSU), but in the Zoea II and III stages, this range tended to narrow and to shift towards higher salinities (35-45 PSU). These trends reversed in the Megalopa and Crab I, where maximum growth occurred again in a wider range and at lower salinities (15-35 PSU). The reduction of zoeal growth in moderately dilute media (15-25 PSU), which were optimal for survival and development, is interpreted as an energetic cost of hyperosmoregulation, which begins already at hatching. Five PSU caused hypo-osmotic stress, exceeding in the long term the larval capacity for hyper-regulation. Poor zoeal survival and growth at 55 PSU are interpreted as effects of hyper-osmotic stress. In the Megalopa and Crab I, reduced growth at salinities $\geq 35$ PSU may reflect the energetic costs of hypo-osmoreguation beginning in these stages. Our data suggest that the physiological adaptations of larval and early juvenile $A$. miersii allowing for survival and development in a physically harsh and unpredictable habitat imply a trade-off with reduced growth, due to energetic costs of osmoregulation.
\end{abstract}

\section{Introduction}

Among the marine Brachyura, the family Grapsidae is known for its pronounced tendency to adapt to nonmarine conditions. Numerous grapsid crab species live in estuarine and intertidal habitats, and several have become fully terrestrial or limnic (Hartnoll, 1988; Anger, 1995a). A neotropical marine species, Armases miersii (Rathbun, 1897), has only recently been recognized as a particularly successful invader in boundary habitats between marine, freshwater and terrestrial environments, namely in the coastal mangrove fringe of Jamaica and, probably, other Caribbean islands (Anger, 1995b, c, 1996; Anger \& Schultze, 1995;
Schuh \& Diesel, 1995a, b). On the limestone coasts of northern Jamaica, A. miersii passes its larval development in ephemeral supratidal rock pools, where highly variable and sometimes extreme conditions of salinity, temperature, $\mathrm{pH}$, oxygen concentration and food availability occur (Anger, 1995b, c, Schuh \& Diesel, 1995a). Hence, the larval stages of this species have evolved an array of physiological adaptations to typically unpredictable environmental variations in their 'nursery' habitat. For instance, A. miersii larvae are facultatively lecithotrophic, ensuring their survival and development in a generally food-limited environment (Anger, 1995b, c). As an adaptation to salinity variations occurring in supratidal rock pools, the lar- 
vae show an extremely euryhaline response, tolerating both brackish and hypersaline conditions (Anger, 1995c, 1996; Schuh \& Diesel, 1995b). This tolerance is based upon strong osmoregulatory capabilities in all postembryonic life-history stages (Charmantier et al., 1998).

The present paper describes ontogenetic patterns in larval and early juvenile growth of A. miersii (measured as rates of increase in the biomass of successive developmental instars) during an experimental exposure to various salinity conditions that occur also in their natural habitat (5-55 PSU; Anger, 1995b; Schuh \& Diesel, 1995a). These results are compared with recent observations of survival and development under identical conditions (Anger, 1996) and with the ontogeny of osmoregulation in this species (Charmantier et al., 1998). In order to differentiate between long-term (chronic) and short-term (acute) effects of osmotic stress, we exposed the larval stages (Zoea I, II, III, Megalopa) and the first juvenile (Crab I) not only continually (from hatching), but also separately (after rearing in seawater) to the different test salinities.

\section{Materials and methods}

Larvae of Armases miersii were obtained from laboratory-cultured ovigerous females that were kept in aquaria with seawater (32-33 PSU; $25^{\circ} \mathrm{C}$ ) under a 12:12 h light:dark regime. The parent generation originated from animals that had been collected in 1993 near the Discovery Bay Marine Laboratory, Jamaica (for further details see Anger, 1996). The larvae were mass-reared in ca. $400 \mathrm{ml}$ glass bowls with freshly hatched Artemia spec. nauplii (ca. $10 \mathrm{ml}^{-1}$ ) given daily as food. Maximum rearing density was 50 individuals per bowl in the Zoea I and II stages, 30 in the Zoea III and 20 in the Megalopa and Crab I. The Megalopa and first juvenile crab instars were given a piece of nylon gauze ( $200 \mu \mathrm{m}$ mesh size) as a substrate.

In five subsequent series of laboratory experiments, larval and early juvenile crabs were reared at six salinities $(5,15,25,35,45,55$ PSU), and rates of growth were measured in short intervals; in parallel experiments with the same material, effects of salinity on larval survival and development duration were studied (see Anger, 1996). The present paper describes effects of salinity on growth in terms of biomass increase (see below for details). In one experimental series, the exposure to the different test salinities began within $12 \mathrm{~h}$ after hatching, and it
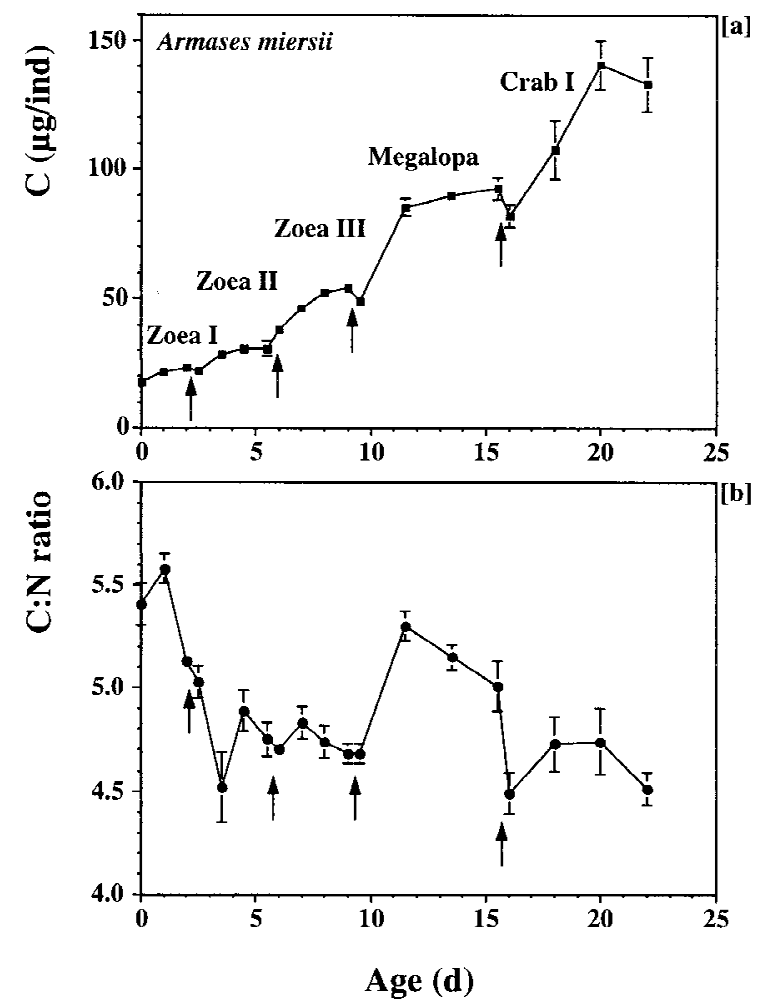

Figure 1. Growth and elemental composition of larval and early juvenile Armases miersii during development (days from hatching) at constant 35 PSU. (a) Carbon content (C) $\left(\mu \mathrm{g}\right.$ ind $\left.^{-1}\right)$, (b) carbon:nitrogen $(\mathrm{C}: \mathrm{N})$ weight ratio. $\bar{x} \pm \mathrm{SD}(n=5$; where no error bars are visible, SD smaller than plot symbol); arrows indicate the time of moulting to subsequent stages.

continued through all four larval stages and the first juvenile crab instar. In the other four series, larvae were reared in seawater (32-33 PSU), where also hatching had taken place, and exposed only in later developmental stages (Zoea II, Zoea III, Megalopa or Crab I) to the various test salinities. Thus, this study comprised five sets of experiments beginning from five different stages, with six treatments each. Since this experimental design required a large amount of material, the number of larvae produced by a single female did not suffice for carrying out the entire study and a different hatch had to be used in each series. Only the results of the first experimental series (exposure from hatching) are documented (Table 1), because this protocol allows for a safe separation of maternal and environmental effects; the results from the other series are briefly described within graphs (Figures 2 and 4) and in the text.

Salinities < 32 PSU were obtained by dilution of filtered $(1 \mu \mathrm{m})$ seawater with desalinated water, higher 
Table 1. Biomass and elemental composition of larval and early juvenile Armases miersii in relation to age within successive instars, during continual exposure (from hatching) to different salinities, dry weight (W), carbon (C), nitrogen (N), hydrogen (H) in $\mu \mathrm{g}$ per individual; C, $\mathrm{N}, \mathrm{H}$ in\% of weight; C:N weight ratio; Zoea II - Crab I: only final biomass (on day of moulting) shown; arithmetic mean $(\bar{x}) n=5$ replicate analyses

\begin{tabular}{|c|c|c|c|c|c|c|c|c|c|c|c|c|c|c|c|c|c|c|}
\hline \multirow[t]{2}{*}{ Stage } & \multirow[t]{2}{*}{$\begin{array}{l}\text { Age } \\
{[\mathrm{d}]}\end{array}$} & \multirow[t]{2}{*}{$\begin{array}{c}\text { Salinity } \\
{[\mathrm{PSU}]}\end{array}$} & \multicolumn{2}{|c|}{$\begin{array}{c}\mathrm{W} \\
{\left[\mu \mathrm{g}^{-1} \mathrm{in}^{-1}\right]}\end{array}$} & \multicolumn{2}{|c|}{$\begin{array}{c}\mathrm{C} \\
{\left[\mu \mathrm{g} \mathrm{ind}^{-1}\right]}\end{array}$} & \multicolumn{2}{|c|}{$\begin{array}{c}\mathrm{N} \\
{\left[\mu \mathrm{g} \mathrm{ind}^{-1}\right]}\end{array}$} & \multicolumn{2}{|c|}{$\begin{array}{c}\mathrm{H} \\
{\left[\mu \mathrm{g} \mathrm{ind}^{-1}\right]}\end{array}$} & \multicolumn{2}{|c|}{$\begin{array}{c}\mathrm{C} \\
{[\%]}\end{array}$} & \multicolumn{2}{|c|}{$\begin{array}{c}\mathrm{N} \\
{[\%]}\end{array}$} & \multicolumn{2}{|r|}{$\begin{array}{c}\mathrm{H} \\
{[\%]}\end{array}$} & \multicolumn{2}{|c|}{$\mathrm{C}: \mathrm{N}$} \\
\hline & & & $\bar{x}$ & $\overline{\text { std.dev. }}$ & $\bar{x}$ & std.dev. & $\bar{x}$ & std.dev. & $\bar{x}$ & std.dev. & $\bar{x}$ & std.dev. & $\overline{\bar{x}}$ & std.dev. & $\bar{x}$ & std.dev. & $\bar{x}$ & std.dev. \\
\hline \multirow[t]{13}{*}{ Zoea I } & 0 & 32 & 38.3 & 1.3 & 17.5 & 0.7 & 3.2 & 0.1 & 2.4 & 0.1 & 45.7 & 0.6 & 8.5 & 0.1 & 6.4 & 0.2 & 5.41 & 0.10 \\
\hline & 1 & 5 & 39.4 & 1.5 & 18.9 & 0.7 & 3.4 & 0.1 & 2.6 & 0.1 & 48.0 & 0.4 & 9.0 & 0.1 & 6.7 & 0.2 & 5.53 & 0.06 \\
\hline & 1 & 15 & 44.4 & 1.4 & 21.3 & 0.7 & 3.9 & 0.1 & 2.9 & 0.1 & 47.6 & 0.3 & 8.7 & 0.1 & 6.6 & 0.2 & 5.49 & 0.05 \\
\hline & 1 & 25 & 47.4 & 1.5 & 21.0 & 0.8 & 3.7 & 0.1 & 3.0 & 0.2 & 44.2 & 0.5 & 7.9 & 0.1 & 6.4 & 0.3 & 5.60 & 0.07 \\
\hline & 1 & 35 & 49.9 & 2.4 & 21.9 & 1.1 & 3.9 & 0.2 & 3.1 & 0.2 & 43.9 & 0.2 & 7.9 & 0.1 & 6.3 & 0.1 & 5.58 & 0.07 \\
\hline & 1 & 45 & 52.9 & 2.3 & 22.0 & 1.4 & 4.0 & 0.3 & 3.2 & 0.2 & 41.6 & 0.9 & 7.6 & 0.2 & 6.0 & 0.1 & 5.46 & 0.10 \\
\hline & 1 & 55 & 50.7 & 2.2 & 19.7 & 1.4 & 4.0 & 0.2 & 2.8 & 0.2 & 38.8 & 1.2 & 7.9 & 0.3 & 5.6 & 0.2 & 4.91 & 0.28 \\
\hline & 2 & 5 & 49.4 & 1.6 & 21.3 & 0.8 & 3.9 & 0.7 & 3.0 & 0.1 & 43.2 & 0.4 & 7.9 & 1.6 & 6.1 & 0.1 & 5.64 & 0.01 \\
\hline & 2 & 15 & 45.5 & 1.6 & 22.1 & 0.9 & 4.3 & 0.1 & 3.2 & 0.2 & 48.5 & 0.5 & 9.5 & 0.1 & 6.9 & 0.2 & 5.13 & 0.07 \\
\hline & 2 & 25 & 49.7 & 2.8 & 23.2 & 0.9 & 4.6 & 0.2 & 3.3 & 0.2 & 46.7 & 1.4 & 9.2 & 0.2 & 6.7 & 0.2 & 5.07 & 0.05 \\
\hline & 2 & 35 & 50.9 & 1.3 & 23.5 & 0.3 & 4.6 & 0.1 & 3.4 & 0.1 & 46.1 & 0.9 & 9.0 & 0.2 & 6.7 & 0.1 & 5.13 & 0.04 \\
\hline & 2 & 45 & 51.9 & 2.4 & 23.7 & 0.7 & 4.6 & 0.1 & 3.4 & 0.1 & 45.7 & 2.0 & 8.8 & 0.4 & 6.6 & 0.2 & 5.20 & 0.04 \\
\hline & 2 & 55 & 50.8 & 2.3 & 21.8 & 1.0 & 4.2 & 0.2 & 3.2 & 0.2 & 43.0 & 0.6 & 8.2 & 0.2 & 6.3 & 0.2 & 5.26 & 0.10 \\
\hline \multirow[t]{6}{*}{ Zoea II } & 3 & 5 & 85.9 & 1.5 & 35.3 & 0.9 & 7.4 & 0.2 & 5.0 & 0.2 & 41.0 & 0.5 & 8.6 & 0.0 & 5.8 & 0.1 & 4.76 & 0.04 \\
\hline & 2 & 15 & 95.8 & 4.2 & 38.3 & 1.6 & 8.0 & 0.3 & 5.7 & 0.3 & 40.0 & 0.4 & 8.4 & 0.1 & 5.9 & 0.1 & 4.76 & 0.05 \\
\hline & 2 & 25 & 105.2 & 4.7 & 41.7 & 2.3 & 8.8 & 0.5 & 6.3 & 0.4 & 39.6 & 0.5 & 8.4 & 0.1 & 5.9 & 0.1 & 4.73 & 0.01 \\
\hline & 2 & 35 & 103.5 & 4.1 & 44.8 & 1.3 & 9.3 & 0.3 & 6.5 & 0.2 & 43.3 & 0.6 & 9.0 & 0.2 & 6.3 & 0.1 & 4.82 & 0.05 \\
\hline & 3 & 45 & 111.8 & 2.3 & 46.0 & 1.3 & 9.4 & 0.3 & 6.9 & 0.2 & 41.2 & 1.1 & 8.4 & 0.2 & 6.1 & 0.2 & 4.92 & 0.07 \\
\hline & 3 & 55 & 79.3 & 8.3 & 32.3 & 1.1 & 6.5 & 0.2 & 4.7 & 0.2 & 41.0 & 4.3 & 8.3 & 0.9 & 5.9 & 0.7 & 4.97 & 0.08 \\
\hline \multirow[t]{6}{*}{ Zoea III } & 4 & 5 & 95.8 & 2.1 & 42.0 & 0.6 & 9.8 & 0.2 & 6.3 & 0.1 & 43.8 & 0.5 & 10.2 & 0.2 & 6.6 & 0.1 & 4.29 & 0.07 \\
\hline & 3 & 15 & 118.7 & 4.7 & 51.4 & 2.3 & 11.2 & 0.4 & 7.5 & 0.4 & 43.3 & 0.4 & 9.4 & 0.2 & 6.3 & 0.1 & 4.59 & 0.08 \\
\hline & 3 & 25 & 125.5 & 2.5 & 56.2 & 1.4 & 12.2 & 0.2 & 8.7 & 0.3 & 44.8 & 0.3 & 9.8 & 0.0 & 6.9 & 0.1 & 4.60 & 0.05 \\
\hline & 3 & 35 & 129.2 & 2.4 & 57.6 & 1.8 & 12.5 & 0.3 & 9.0 & 0.3 & 44.6 & 0.9 & 9.6 & 0.1 & 7.0 & 0.2 & 4.62 & 0.07 \\
\hline & 4 & 45 & 137.6 & 4.0 & 60.4 & 2.1 & 12.9 & 0.3 & 9.4 & 0.4 & 43.9 & 0.4 & 9.4 & 0.1 & 6.9 & 0.1 & 4.67 & 0.06 \\
\hline & 5 & 55 & 124.3 & 1.9 & 53.0 & 0.5 & 11.2 & 0.3 & 8.3 & 0.1 & 42.7 & 0.5 & 9.0 & 0.1 & 6.7 & 0.1 & 4.72 & 0.06 \\
\hline \multirow[t]{4}{*}{ Megalopa } & 6 & 15 & 221.4 & 8.8 & 89.0 & 3.3 & 18.5 & 0.5 & 12.9 & 0.5 & 40.2 & 0.6 & 8.3 & 0.2 & 5.8 & 0.1 & 4.82 & 0.06 \\
\hline & 6 & 25 & 236.2 & 9.9 & 95.9 & 3.2 & 19.3 & 0.5 & 14.1 & 0.5 & 40.6 & 0.7 & 8.2 & 0.1 & 6.0 & 0.1 & 4.96 & 0.09 \\
\hline & 6 & 35 & 246.2 & 5.7 & 98.4 & 2.6 & 19.7 & 0.4 & 14.6 & 0.5 & 40.0 & 1.3 & 8.0 & 0.2 & 5.9 & 0.2 & 5.01 & 0.04 \\
\hline & 7 & 45 & 232.0 & 11.2 & 88.6 & 4.0 & 18.9 & 0.8 & 12.9 & 0.6 & 38.2 & 1.0 & 8.2 & 0.3 & 5.6 & 0.1 & 4.68 & 0.12 \\
\hline \multirow[t]{4}{*}{ Crab I } & 5 & 15 & 431.9 & 25.4 & 155.9 & 10.0 & 31.8 & 2.1 & 21.2 & 1.8 & 36.1 & 0.6 & 7.4 & 0.1 & 4.9 & 0.2 & 4.90 & 0.06 \\
\hline & 5 & 25 & 406.2 & 32.7 & 145.0 & 10.4 & 29.4 & 2.1 & 21.6 & 1.5 & 35.6 & 0.7 & 7.5 & 0.3 & 5.2 & 0.2 & 4.94 & 0.05 \\
\hline & 5 & 35 & 412.0 & 18.5 & 144.9 & 6.7 & 30.0 & 1.5 & 21.8 & 1.2 & 35.2 & 0.3 & 7.3 & 0.1 & 5.3 & 0.1 & 4.83 & 0.08 \\
\hline & 5 & 45 & 390.4 & 19.5 & 134.4 & 8.0 & 28.3 & 1.6 & 20.1 & 1.3 & 34.4 & 0.6 & 7.2 & 0.1 & 5.1 & 0.1 & 4.75 & 0.04 \\
\hline
\end{tabular}

concentrations by freezing seawater at $-18{ }^{\circ} \mathrm{C}$. Salinities were checked with a temperature-compensated electric probe (WTW, Germany) or a hand refractometer (Krüss Salinometer S-28) to the nearest 0.1 or 1 PSU, respectively. Transfer of larvae or juveniles to 25 and 45 PSU was direct, whereas that to higher or lower salinities allowed for a stepwise adaptation (3 h per interval). Charmantier et al. (1998) showed that an adaptation time of ca. $2 \mathrm{~h}$ is sufficient for the early developmental stages of $A$. miersii to reach a constant haemolymph concentration. During daily water change and feeding, larvae and juveniles were checked for moults or mortality. Freshly moulted individuals were transferred to new marked bowls, so that each bowl contained exclusively individuals with an identical age within the moulting cycle of a given stage. Growth in the successive postembryonic instars was measured in terms of dry weight (W), carbon $(\mathrm{C})$, nitrogen $(\mathrm{N})$ and hydrogen $(\mathrm{H})$. W was measured to the nearest $0.1 \mu \mathrm{g}$ on a Mettler UM3 microbalance, and $\mathrm{C}, \mathrm{N}$ and $\mathrm{H}$ with a model 1108 Carlo Erba CHN Analyser applying standard techniques (Anger \& Harms, 1990). After exposure of a given developmental stage to the different test salinities, five rep- 

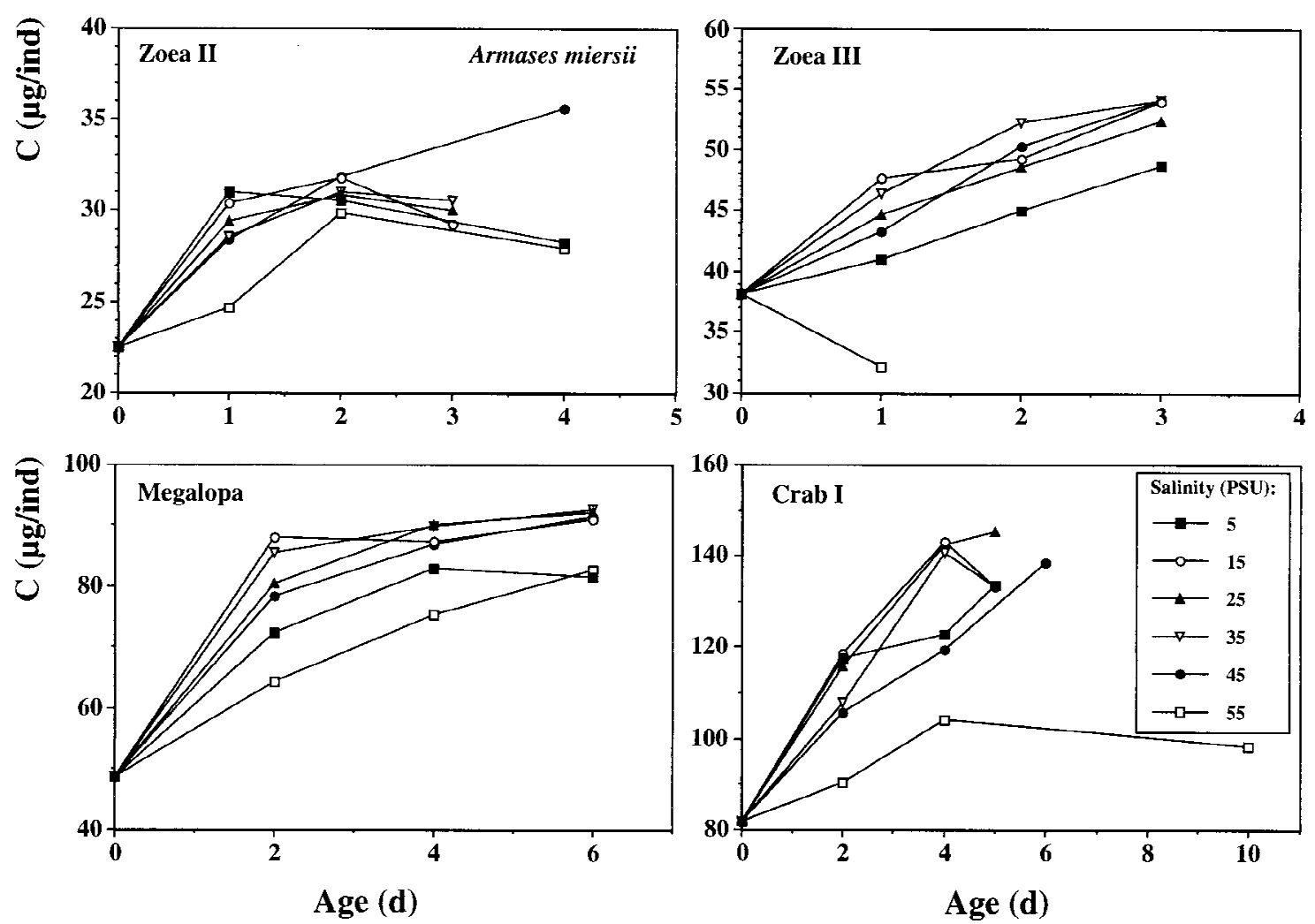

Figure 2. Growth (expressed as carbon content, $\mathrm{C}\left(\mu \mathrm{g}\right.$ ind $\left.{ }^{-1}\right)$ of larval and early juvenile Armases miersii after acute exposure to different salinities (5-55 PSU; preceding development to each stage in seawater, 32-33 PSU); age (days) within the moulting cycle of a given stage; no error bars given for sake of clarity.

licate samples with 4-6 individuals each were taken daily (zoeal stages) or every other day (Megalopa, Crab I) and stored frozen at $-20{ }^{\circ} \mathrm{C}$ until analysis. In the experimental series with exposure from hatching, growth was followed also through subsequent stages (with samples of final biomass only). When moulting began in a bowl, it was assumed that all individuals in the earlier stage were approaching the end of the moulting cycle and their biomass thus represented the final value in a given stage.

All statistical analyses followed standard techniques (Sokal \& Rohlf, 1995). When data deviated significantly from a normal distribution (KolmogorovSmirnov test) or when variances deviated significantly from homogeneity (Levene's median test), the nonparametric Mann-Whitney rank sum test was used for comparisons of mean values, otherwise Student's $t$-test.

\section{Results}

When freshly hatched Armases miersii larvae were transferred from seawater (32 PSU) to the different rearing salinities (5-55 PSU), they exhibited in the full range of conditions a significant biomass accumulation, although this was consistently and significantly depressed at 5 and 55 PSU. The patterns of growth within individual developmental stages were similar in all experimental series and treatments (except for 55 PSU, where also losses of biomass occurred), regardless of the measure of biomass considered (W, C, $\mathrm{N}$ or $\mathrm{H}$; as shown in Table 1 ).

This general pattern in biomass accumulation is exemplified with the carbon (C) content per individual during development at constant seawater conditions (35 PSU; Figure 1a). Growth in later stages, after acute exposure to different salinities, is shown in Figure 2. In general, a steep biomass increase occurred in the first half of the moulting cycle, followed by weaker increments, and eventually, often by constant or slightly decreasing $\mathrm{C}$ values when moulting was approached. During development at 35 PSU from the Zoea I (hatching) to the end of the Megalopa stage (metamorphosis), larval dry weight increased by a 


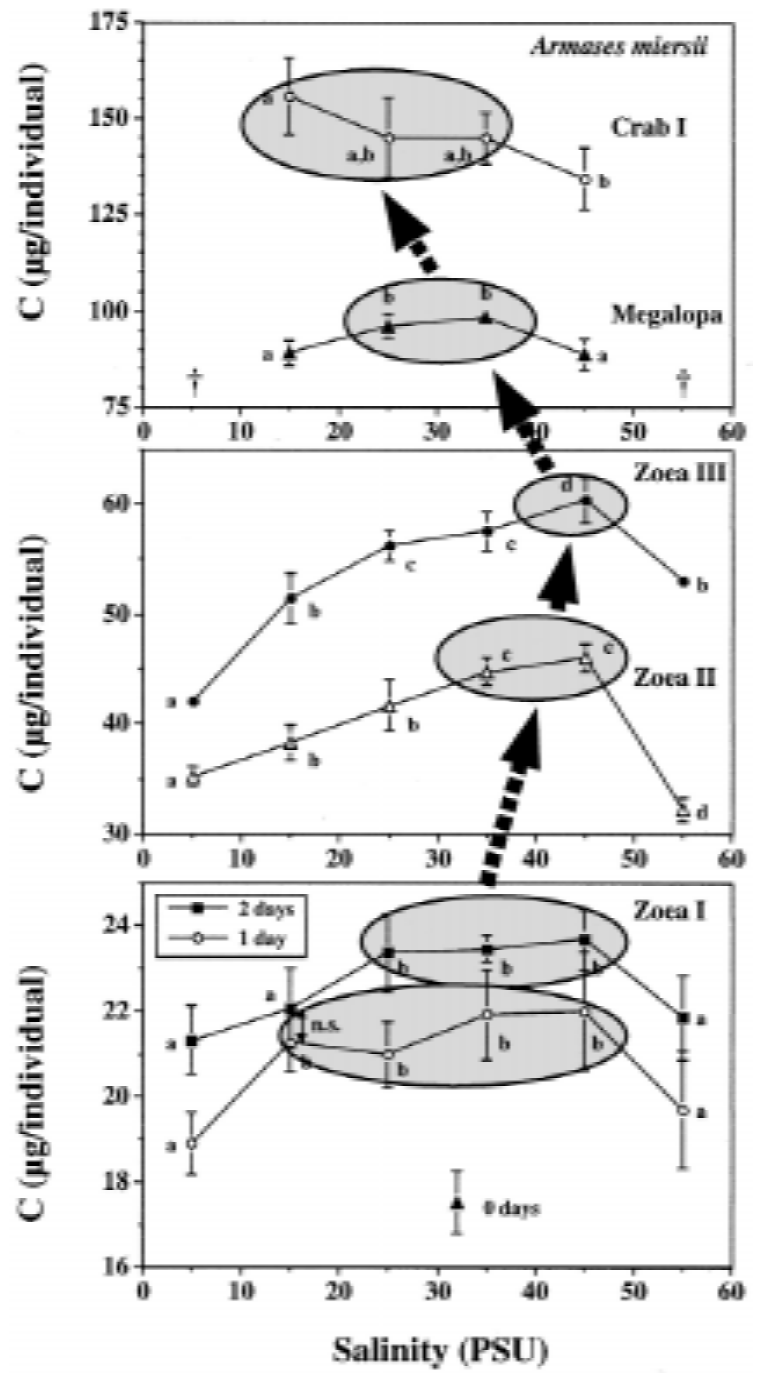

Figure 3. Growth (expressed as carbon content, $\mathrm{C}\left(\mu \mathrm{g}\right.$ ind $\left.^{-1}\right)$ of larval and early juvenile Armases miersii during development at different salinities (5-55 PSU; exposure from hatching); $\bar{x} \pm \mathrm{SD}$ $(n=5)$; different letters indicate significant differences between salinities; $\dagger$ : complete mortality in indicated stage. Salinity range allowing for maximum growth and ontogenetic shifts in the apparent optimum for growth marked with shaded areas and arrows, respectively; maximum growth defined by maximum $\mathrm{C}$ content and values that were not significantly different from this.

factor of $6.0, \mathrm{C}$ by $5.3, \mathrm{~N}$ by 5.8 and $\mathrm{H}$ by 5.6 . Similar cumulative increments were measured during development at 25 PSU, while a slight but statistically significant depression occurred at 15 and 45 PSU.

At the two extreme salinities (5 and 55 PSU, resp.), development was generally delayed, so that the final biomass of successive instars was reached later than in the other treatments (see Zoea II, III, Megalopa in Table 1). In spite of the lengthened time available for growth, developmentally delayed individuals showed in most cases a significantly lower final biomass than siblings reared under more favourable conditions (exception: Zoea II at 45 PSU; Figure 2). Compared with 25 and 35 PSU, the duration of development in the Crab I stage was doubled at 55 PSU, and the increment in $\mathrm{C}$ was reduced to one half. Similar although weaker stress effects occurred at 5 and 45 PSU.

Similar patterns as in the $\mathrm{C}$ content were observed also in $\mathrm{N}$ and $\mathrm{H}$ per individual (Table 1). This indicates that the relative chemical composition of biomass remained fairly constant in most treatments. Significantly reduced percentage values of $\mathrm{C}, \mathrm{N}$ and $\mathrm{H}$, however, occurred in most stages under the exposure to very high salinities (55 PSU, sometimes also 45 PSU; see Table 1), indicating a stress-induced reduction of organic matter in relation to inorganic compounds. No consistent salinity effects were observed in the $\mathrm{C}: \mathrm{N}$ weight ratio, which is generally considered as an indicator of changes in the lipid:protein relation.

Independent of the salinity, there were clear ontogenetic changes in the $\mathrm{C}: \mathrm{N}$ ratio (Figure $1 \mathrm{~b}$; Table 1). This quotient decreased gradually throughout the zoeal phase, indicating a preferential degradation of lipid stores and/or a proportionally faster accumulation of protein. This decrease was followed by an increase in the Megalopa stage (again in all treatments), and low values after metamorphosis to the first juvenile crab.

Effects of chronic exposure to different salinities (from hatching) on larval and early juvenile growth are illustrated in Figure 3, using again the $\mathrm{C}$ content per individual as an example. In the first zoeal stage, initial growth was only at the two extreme salinites (5, 55 PSU) significantly reduced, while maximum $\mathrm{C}$ increments occurred in a wide intermediate range (15-45 PSU). Subsequently, however, the range allowing for maximum $\mathrm{C}$ accumulation tended to narrow and the optimum for growth (shaded areas in Figure 3) appeared to shift towards higher concentrations (arrows). These tendencies continued throughout the zoeal phase (Zoea I-III), but reversed thereafter. In the Megalopa and Crab I, maximum final biomass values were measured again in a wider range, including seawater and moderately brackish conditions (15-35 PSU). In order to allow for direct comparisons of growth data from different stages, treatments or experimental series (the latter measured in larvae from different females), we converted the biomass increments (in $\mu \mathrm{g} \mathrm{C}$ per instar) to percentage values, defining the increments in the seawater (35 PSU) treatment as 'control' $(=100 \%)$ values. In this presentation, 

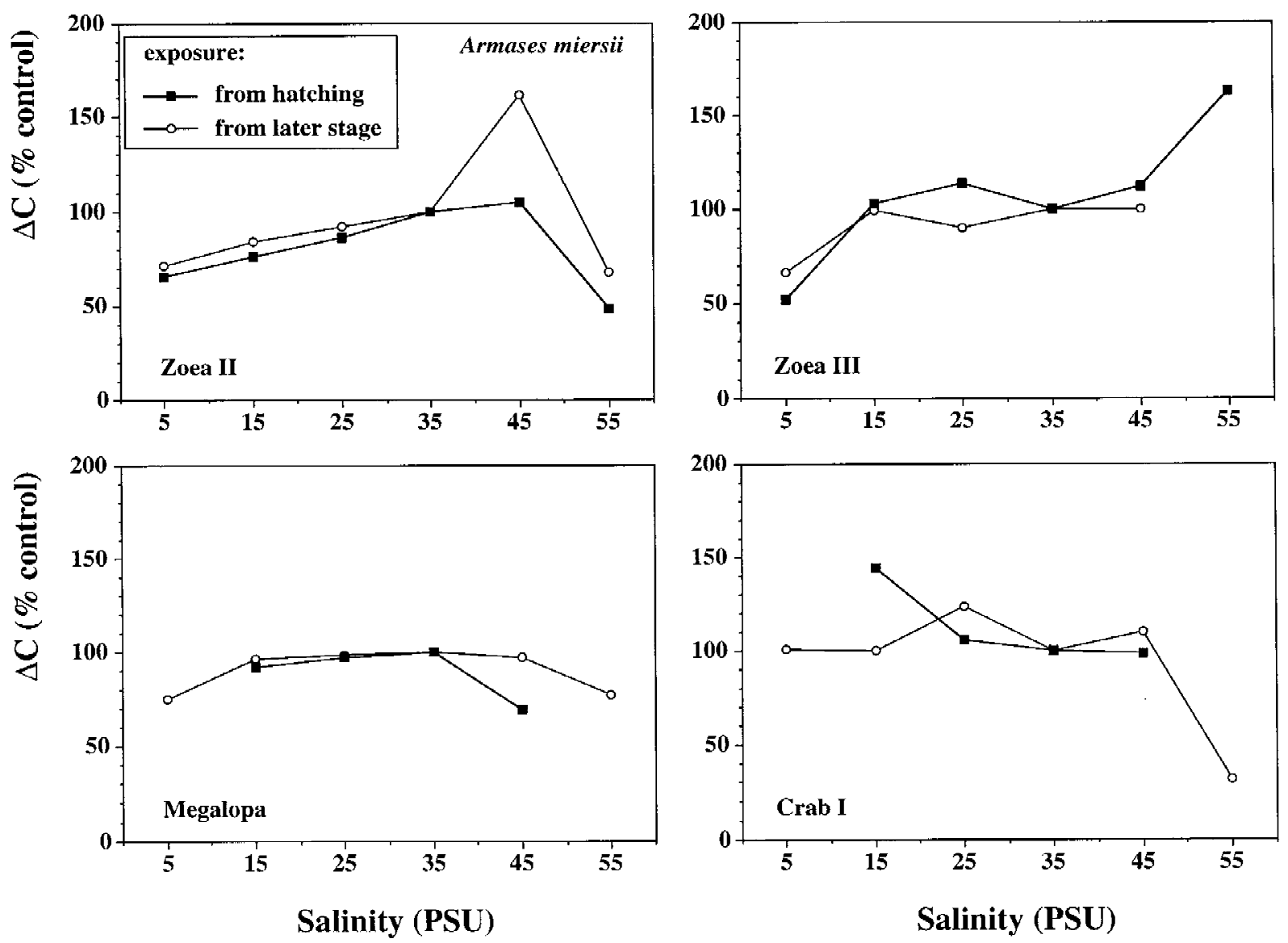

Figure 4. Relative carbon growth increments $(\Delta \mathrm{C}[\%])$ in larval and early juvenile Armases miersii during development at different salinities (5-55 PSU), after exposure either from hatching (filled squares) or only in a later stage (open circles); $\triangle \mathrm{C}$ expressed as a percentage of the $\mathrm{C}$ increment measured in a control condition (35 PSU).

mostly similar response patterns were found in experiments with either continuous or acute exposure to salinities ranging from 15 to $25 \mathrm{PSU}$, suggesting only insignificant effects of the timing of exposure (Figures 2 and 4). However, extreme conditions (5 and 55 PSU, resp., to some degree also 45 PSU) tended to affect growth stronger in experiments with chronic as compared with later beginning exposure (Zoea II, Megalopa in Figure 4).

\section{Discussion}

The present investigation confirms that the early lifehistory stages of Armases miersii are physiologically well adapted for survival and development in a physically harsh and unpredictable environment. Substantial biomass accumulation occurred in a wide range of salinities, comprising highly dilute brackish water (5
PSU), as well as hypersaline conditions (55 PSU). From a recent study of the ontogeny of osmoregulation in this species (Charmantier et al., 1998), we know that the extreme euryhalinity of the larval and early juvenile stages is based upon an unusually early appearance of osmoregulatory capabilities, including hyper-regulation from hatching of the Zoea I and hypo-regulation from the Megalopa stage.

Except for the most unfavourable condition (55 PSU), salinity did not greatly affect the patterns of growth within individual moulting cycles (Figure 2) or the relative chemical composition of biomass (Table 1). The parabola-shaped growth curves within successive developmental stages (Figure 1a) are typical of planktotrophic decapod crustacean larvae (Anger, 1998), although the overall level of biomass increase per moulting cycle appears to be exceptionally low in A. miersii. This was noted already in a preliminary study (Anger \& Schultze, 1995) and interpreted as a 
consequence of partial utilization of enhanced internal energy reserves remaining from the egg yolk. These reserves enable the early larvae of this species to survive and develop, when necessary, also with limited or lacking planktonic food sources (Anger, 1995b). A relationship between particularly low zoeal growth and a high endotrophic potential was observed also in other decapod species that have partially emancipated from the sea (Anger, 1995a).

The present results corroborate this generalization. A decreasing $\mathrm{C}: \mathrm{N}$ ratio during the early zoeal phase (Figure 1b) suggests a partial utilization of lipid reserves (predominantly stored in the hepatopancreas) and/or a concomitant synthesis of proteins (probably in nervous, muscular and epidermal tissues; Harzsch \& Dawirs, 1993). A rapid initial increase in the C:N quotient after the moult to the Megalopa, by contrast, may reflect an increasing feeding activity in this stage (Anger, 1995b), and hence, an increasing lipid accumulation. Additionaly, however, there is a rapid initial cuticle calcification in the Megalopa, which should enhance the proportion of inorganic $\mathrm{C}$ within total dry weight, and thus, of total $\mathrm{C}$ in relation to $\mathrm{N}$ (Anger, 1998).

The biomass increments in successive stages were, in general, relatively little influenced by salinity, showing a conspicuous depression only at the most extreme conditions (5 and 55 PSU, resp.). Also the timing of exposure was not a very important factor in the salinity tolerance pattern of A. miersii larvae (Figure 4). As an overall tendency, later (acute) exposure to unfavourable salinites appeared to affect growth to a slightly lesser degree than long-term exposure. This corresponds with our observations of survival and development duration (Anger, 1996), where consistently a wider salinity range was tolerated in experiments with short-term as compared with chronic exposure. This response pattern indicates cumulative effects of continued osmotic stress. When the salinity range allowing for maximum growth (shaded areas in Figure 3 ) is compared with the optimum for survival and development (Anger, 1996), there appears to be a striking difference in the response patterns. The rates of survival and development were generally maximal in moderately dilute media (15-25 PSU), which corresponds with the prevailing conditions in natural breeding rock pools in spring on Jamaica (Anger, 1995b; Schuh \& Diesel, 1995a, b). The salinity conditions allowing for maximum growth, by contrast, showed conspicuous ontogenetic changes. During development at 15-25 PSU, zoeal biomass accumulation was lower than in higher salt concentrations (35-45 PSU), and the initially wide salinity range with maximum growth tended to narrow throughout the zoeal phase (Figure 3). We interpret this as a consequence of cumulative energetic costs for hyper-osmoregulation in dilute media (Charmantier et al., 1998). At higher salinities, by contrast, the zoeal stages behave as osmoconformers, and hence, they do not invest significant amounts of energy in osmoregulation. We propose that this energy saving effect allows for maximum growth at 35-45 PSU, although other physiological processes associated with development and maintenance may not function at their optimum.

In the Megalopa and Crab I, the range of salinities allowing for maximum $\mathrm{C}$ accumulation appears to widen again, shifting back towards lower salt concentrations (Figure 3). This may be explained with two major ontogenetic changes. 1 . The efficiency of hyperosmoregulation in dilute media ( $\leq 25$ PSU) should significantly increase, due to the appearance of functional gills and an enlargement of other transport epithelia (Charmantier, 1998). As a consequence of a reduction in the energetic costs for hyper-osmoregulation, more energy should become available for growth in brackish water. 2. In the Megalopa stage, A. miersii attains also the capability of hypo-regulation in concentrated media. Reduced growth in the Megalopa and Crab I at high salinities ( $\geq 35$ PSU) may thus reflect an increasing energy demand for hypoosmoregulation. When these late stages were exposed, without prior acclimatization, to enhanced salinities, also their mortality and development rates indicated particularly strong osmotic stress (Anger, 1996). The results of our studies of salinity tolerance and growth in the early life-history stages of A. miersii show consistently that this species is very well adapted to pass its larval and early juvenile development in supratidal rock pools, where great salinity variations occur. However, partially incongruous response patterns in survival, development and growth suggest that the adaptation of this semiterrestrial crab to non-marine conditions is not perfect. Reduced growth under otherwise optimum salinity conditions, presumably due to the energetic costs of osmoregulation, may indicate a trade-off between different physiological adaptations. Similar as in the partial independence from planktonic food sources (Anger, 1995a, b), the salinity tolerance of larval A. miersii appears to reflect a transitional stage in the evolutionary process of a crab species that is about to invade limnic and terrestrial environments. 


\section{References}

Anger, K., 1995a. The conquest of freshwater and land by marine crabs: adaptations in life-history patterns and larval bioenergetics. J. exp. mar. Biol. Ecol. 193: 119-145.

Anger, K., 1995b. Developmental biology of Armases miersii (Grapsidae), a crab breeding in supratidal rock pools. I. Facultative lecithotrophy of larval stages. Mar. Ecol. Prog. Ser. 117: 75-81.

Anger, K., 1995c. Developmental biology of Armases miersii (Grapsidae), a crab breeding in supratidal rock pools. II. Food limitation in the nursery habitat and larval cannibalism. Mar. Ecol. Prog. Ser. 117: 83-89.

Anger, K., 1996. Salinity tolerance of the larvae and first juveniles of a semiterrestrial grapsid crab, Armases miersii (Rathbun). J. exp. mar. Biol. Ecol. 202: 205-223.

Anger, K., 1998. Patterns of growth and chemical composition in decapod crustacean larvae. Invert. Reprod. Develop. 33: 159176.

Anger, K. \& J. Harms, 1990. Elemental (CHN) and proximate biochemical composition of decapod crustacean larvae. Comp. Biochem. Physiol. 97B: 69-80.

Anger, K. \& K. Schultze, 1995. Elemental composition (CHN), growth, and exuvial loss in the larval stages of two semiterrestrial crabs, Sesarma curacaoense and Armases miersii (Decapoda: Grapsidae). Comp. Biochem. Physiol. 111A: 615-623.
Charmantier, G., 1998. Ontogeny of osmoregulation in crustaceans: a review. Invert. Reprod. Develop 33: 177-190.

Charmantier, G., M. Charmantier-Daures \& K. Anger, 1998. Ontogeny of osmoregulation in the grapsid crab Armases miersii (Crustacea, Decapoda). Mar. Ecol. Prog. Ser. 164: 285-292.

Hartnoll, R. G., 1988. Evolution, systematics, and geographical distribution. In Burggren, W. W. \& B. R. McMahon (eds), Biology of the Land Crabs. Cambridge University Press, New York: 6-54.

Harzsch, S. \& R. R. Dawirs, 1993. On the morphology of the central nervous system in larval stages of Carcinus maenas $\mathrm{L}$. (Decapoda, Brachyura). Helgoländer wiss. Meeresunters. 47: 61-79.

Schuh, M. \& R. Diesel, 1995a. Breeding in a rock pool: larvae of the semiterrestrial crab Armases (=Sesarma)miersii (Decapoda: Grapsidae) develop in a highly variable environment. J. exp. mar. Biol. Ecol. 185: 109-129.

Schuh, M. \& R. Diesel, 1995b. Effects of salinity, temperature and starvation on the larval development of Armases (=Sesarma) miersii (Rathbun, 1897), a semiterrestrial crab with abbreviated development (Decapoda: Grapsidae). J. Crust. Biol. 15: 205-213.

Sokal, R. R. \& F. J. Rohlf, 1995. Biometry. The Principles and Practice of Statistics in Biological Research. W. H. Freeman \& Co., 3rd edn, San Francisco: 887 pp. 